\title{
SPRAWY DOTYCZĄCE KOLEI PAŃSTWOWYCH W PRAKTYCE PRAWNEJ PROKURATORII GENERALNEJ RZECZYPOSPOLITEJ POLSKIEJ W LATACH 1919-1939
}

\section{WSTĘP}

Istotnym elementem gospodarki państwa polskiego w okresie międzywojennym był transport kolejowy. Prawidłowe funkcjonowanie kolejnictwa polskiego związane było m.in. $\mathrm{z}$ wykonywaniem ochrony prawnej interesów majątkowych Skarbu Państwa zaangażowanego w tę sferę działalności gospodarczej. W Polsce dwudziestolecia międzywojennego scentralizowane zastępstwo prawne różnorodnych interesów skarbowych powierzone było Prokuratorii Generalnej Rzeczypospolitej Polskiej ${ }^{1}$. W trakcie prac komisji prawniczej Sejmu Ustawodawczego uznano, że zakres ochrony prawnej Prokuratorii w stosunku do rozwiązań dekretu Tymczasowego Naczelnika Państwa zostanie rozszerzony m.in. o „fundusze państwowych kolei żelaznych”2. Zgodnie

Dr hab. MAREK TKACZUK - adiunkt, Wydział Prawa i Administracji Uniwersytetu Szczecińskiego, ul. Narutowicza 17a, 70-240 Szczecin; e-mail: marek.tkaczuk@usz.edu.pl; ORCID: https://orcid.org/0000-0001-9511-813X.

${ }^{1}$ Dekret z dnia 7 lutego 1919 r. w przedmiocie utworzenia Prokuratorii Generalnej Rzeczypospolitej Polskiej, Dz. Pr. z 1919 r., Nr 14, poz. 181; ustawa z dnia 31 lipca 1919 r. w przedmiocie utworzenia Prokuratorii Generalnej Rzeczypospolitej Polskiej, Dz.U. z 1919 r., Nr 75, poz. 390; Rozporządzenie Prezydenta Rzeczypospolitej z dnia 9 grudnia 1924 r. o zmianie ustroju Prokuratorii Generalnej Rzeczypospolitej Polskiej, Dz.U. z 1924 r., Nr 107, poz. 967; B. SITEK, Wybrane systemy prawnej $i$ instytucjonalnej ochrony praw i interesów państwa, Warszawa: Difin 2020, s. 74.

${ }^{2}$ Sejm Ustawodawczy Rzeczypospolitej Polskiej [dalej: SURP], druk nr 861, Sprawozdanie komisji prawniczej z dnia 19 lipca 1919 r. w sprawie dekretu z dn. 7 lutego 1919 r. (Dz. Pr. Nr 14, poz. 181) w przedmiocie utworzenia Prokuratorii Generalnej Rzeczypospolitej Polskiej, załącznik do druku - art. 3 ust. 1 projektu ustawy w przedmiocie utworzenia Prokuratorii Generalnej Rzeczypospolitej Polskiej. 
z projektem ustawy skarb kolejowy potraktowano jako element Skarbu Państwa, a ministerstwo kolei oraz dyrekcje kolejowe związano obowiązkowym zastępstwem Prokuratorii w sprawach sądowych ${ }^{3}$. Sprawy kolejowe w praktyce Prokuratorii Generalnej przyjmowały także postać pomocy prawnej, m.in. w postaci czynności opiniodawczych.

Do 1926 r. sprawy kolei państwowych należały do kompetencji Prokuratorii Generalnej na mocy ustawowych przepisów dotyczących jej organizacji. W związku z wejściem w życie rozporządzenia Prezydenta Rzeczypospolitej z 24 września 1926 r. kolej państwowa została wyodrębniona z administracji państwowej $\mathrm{w}$ drodze powołania przedsiębiorstwa państwowego mającego osobowość prawną. Rozporządzenie Prezydenta powierzało Prokuratorii Generalnej zastępstwo sądowe przedsiębiorstwa „Polskie Koleje Państwowe” (dalej: PKP) w sprawach jego praw i interesów majątkowych ${ }^{4}$.

W dziale spraw kolejowych dominowały czynności zastępstwa sądowego i stanowiły jedną z obszerniejszych oraz ekonomicznie znaczących czynności w całej praktyce prawnej Prokuratorii ${ }^{5}$. Źródłem agendy była wzmożona działalność organizatorska i inwestycyjna administracji kolejowej, później władz PKP. Przywrócenie zawieszonej w okresie wojennym pełnej odpowiedzialności kolei za działalność przewozową oraz przystąpienie Polski do międzynarodowych konwencji kolejowych także miało wpływ na rozmiar spraw kolejowych.

\section{CHARAKTERYSTYKA SPRAW KOLEJOWYCH}

Do najważniejszych typów spraw kolejowych, zarówno przed jak i po roku 1926, należały problemy dotyczące ustroju kolejowego, w tym pozycji prawnej PKP i relacji do Skarbu Państwa, związków samorządu terytorialnego oraz podmiotów prywatnych, a ponadto sprawy: taryfowe, o odszkodowania za zaginione lub uszkodzone przesyłki, za szkody wywołane ruchem kolei, za wywłaszczenia na rzecz rozwoju sieci kolejowej, własności gruntów i budynków kolejowych oraz stosunków służbowych kolejarzy.

\footnotetext{
${ }^{3}$ SURP, Sprawozdanie stenograficzne, LXXXII-ł. 63, Wystąpienie posła Ćwikowskiego na 82 posiedzeniu Sejmu Ustawodawczego w dniu 31 lipca 1919 r.

${ }^{4}$ Rozporządzenie Prezydenta Rzeczypospolitej z dnia 24 września 1926 r. o utworzeniu przedsiębiorstwa „Polskie Koleje Państwowe”, Dz.U. z 1926 r., Nr 97, poz. 568 - art. 24.

${ }^{5}$ Sprawozdanie Prezesa Prokuratorii Generalnej [dalej: SPPG]-1928, s. 94. Sprawozdania Prezesa Prokuratorii Generalnej wykorzystane w artykule znajdują się m.in. w bibliotece b. Katedry Prawa Rzymskiego, Historii Prawa i Doktryn Polityczno-Prawnych Wydziału Prawa i Administracji Uniwersytetu Szczecińskiego.
} 


\section{Sprawy ustroju kolejowego}

Z chwilą wejścia w życie rozporządzenia komercjalizującego przedsiębiorstwo kolejowe, najistotniejszym problemem prawnym mającym zasadniczy wpływ na praktykę prawną Prokuratorii Generalnej było powstanie odrębnej od Skarbu Państwa zdolności prawnej i zdolności procesowej PKP. Istota problemu związana była $\mathrm{z}$ brakiem właściwych rozporządzeń wykonawczych, w szczególności tych, które dotyczyły powołania organów PKP. Prokuratoria zwróciła się w 1928 r. do Ministra Sprawiedliwości o wywołanie

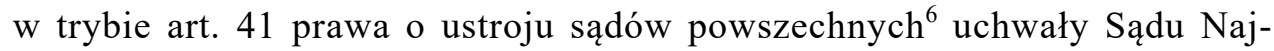
wyższego (dalej: SN) mającej rozstrzygnąć tę kwestię. W 1929 r. SN uznał, że mimo braku rozporządzeń wykonawczych przewidzianych w rozporządzeniu Prezydenta z 1926 r. o utworzeniu PKP, należało uważać PKP za podmiot prawny mający odrębną od Skarbu Państwa zdolność prawną i zdolność procesową. SN uznał także, że PKP stało się podmiotem praw i obowiązków dotyczących kolejnictwa w miejsce Skarbu Państwa ${ }^{7}$. Stanowisko, że niedopuszczalne było pozywanie Skarbu Państwa w sprawach PKP, zostało potwierdzone przez SN w $1935 \mathrm{r}^{8}{ }^{\mathrm{W}} 1936 \mathrm{r}$. SN w kolejnym wyroku wyjaśnił, że jako datę przejścia na PKP wyłącznej legitymacji procesowej w sprawach kolejowych uważać należało dzień 5 sierpnia $1931 \mathrm{r}$. W tym to dniu w Dzienniku Urzędowym Ministerstwa Sprawiedliwości ukazało się ogłoszenie o wpisaniu PKP do rejestru handlowego9.

Do czynności Prokuratorii podejmowanych w zakresie ustroju kolejowego zaliczano także te, które zostały spowodowane działaniem państwa $\mathrm{w}$ stosunku do kolei prywatnych. Źródłem czynności opiniodawczych i zastępstwa prawnego w tej materii było przejmowanie przez Skarb Państwa na własność kolei prywatnych lub prowadzenie na liniach prywatnych przez PKP państwowego ruchu kolejowego. Stosunki prawne, których źródłem były umowy eksploatacyjne, rodziły spory sądowe. Oddział Prokuratorii Generalnej we Lwowie prowadził obronę PKP $\mathrm{w}$ procesie $\mathrm{z}$ powództwa kolei lokalnych „Lwów-Stojanów” o zapłatę pół miliona złotych za używanie części linii tych kolei ${ }^{10}$. Kolej prywatna „Piła-Jaworzno” dochodziła zaś od PKP zapłaty za niezgodne z umową eksploatacyjną stosowanie taryf. Oddział krakowski

\footnotetext{
${ }^{6}$ Rozporządzenie Prezydenta Rzeczypospolitej z dnia 6 lutego 1928 r. - Prawo o ustroju sądów powszechnych, Dz.U. z 1928 r., Nr 12, poz. 93.

${ }^{7}$ Orzeczenie połączonych Izb SN z 8 czerwca 1929 r. Nr I. N 78/29 (SPPG-1929, s. 68).

${ }^{8}$ Wyrok SN z 6 czerwca 1935 r. (SPPG-1935, s. 134).

${ }^{9}$ SPPG-1936, s. 147.

${ }^{10}$ Tamże.
} 
Prokuratorii w 1930 r. wydał opinię interpretującą umowę eksploatacyjną zawartą z koleją „Trzebina-Skawce”" Działania prawne związane były ze sporem kolei prywatnej z PKP o udział w dochodach eksploatacyjnych. W 1931 r. za pośrednictwem Prokuratorii między kolejami zawarta została ugoda ${ }^{12}$.

W 1928 r. Urząd Główny Prokuratorii Generalnej w Warszawie na żądanie władz centralnych brał udział w kilku konferencjach dotyczących spraw związanych z kolejami, których linie zostały przecięte przez nowe, powstałe po I wojnie światowej granice państw. Konferencje obejmowały problematykę prawną związaną z „Koleją Północną Cesarza Ferdynanda” i z „Koleją Lwów-Czerniowce-Jassy”. Władze państwowe postanowiły przejąć na własność te koleje. Prokuratorii polecono zaopiniować odpowiednie akty ${ }^{13}$. Identyczne czynności Prokuratoria podejmowała w sprawach wykupu kolei „HerbyKielce”, kolei „Lwów-Bełżec”, kolejek dojazdowych kujawskich i gosławickich, linii kolejowej należącej do Spółki Akcyjnej „Wschodnio-Galicyjskie Koleje Lokalne”, linii kolejowej „Towarzystwa Kolei Fabrycznej Łódzkiej" i innych linii kolejowych przejmowanych na podstawie ustawy z dnia 14 grudnia 1920 r. o przejęciu kolei zbudowanych przez byłe władze okupacyjne $^{14}$. Podnoszone przez byłych właścicieli roszczenia do Skarbu, jak i kwestie odpowiedzialności Skarbu Państwa za obligacje tych kolei gwarantowane przez byłe państwa zaborcze, także były przedmiotem analiz prawnych Prokuratorii ${ }^{15}$. W kwestiach odpowiedzialności za zobowiązania państw zaborczych sądy z zasady przyjmowały za słuszną linię obrony opierającą się na stanowisku Prokuratorii, że państwo polskie nie przejęło zobowiązań państw zaborczych, pomimo podnoszenia przez przeciwników procesowych argumentu o objęciu tych długów z powodu uznania przedsiębiorstwa za rzecz zbiorową ${ }^{16}$. Jednakże $\mathrm{w}$ jednym $\mathrm{z}$ procesów $\mathrm{z}$ powództwa posiadaczy gwarantowanych przez b. rząd rosyjski obligacji „Kolei Fabrycznej Łódzkiej”

\footnotetext{
${ }^{11}$ SPPG-1930, s. 79.

12 SPPG-1931, s. 101.

${ }^{13}$ SPPG-1928, s. 96.

${ }^{14}$ Ustawa z dnia 14 grudnia 1920 r. o przejęciu kolei zbudowanych przez b. władze okupacyjne, pod zarząd Ministerstwa Kolei Żelaznych, Dz.U. z 1921 r., Nr 3, poz. 5; SPPG-1928, s. 96; SPPG-1929, s. 69; SPPG-1930, s. 79; SPPG-1931, s. 101.

${ }^{15}$ SPPG-1928, s. 96; SPPG-1929, s. 69.

${ }^{16}$ SPPG-1929, s. 69. Odnośnie do udziału Prokuratorii Generalnej w ustaleniu w orzecznictwie polskim stanowiska, że odrodzone państwo polskie nie ponosiło odpowiedzialności za zobowiązania państw zaborczych: M. TKACZUK, Sprawy międzynarodowe $w$ praktyce prawnej Prokuratorii Generalnej RP w dwudziestoleciu międzywojennym, [w:] Wielokulturowość polskiego pogranicza. Ludzie - idee - prawo, red. A. Lityński, P. Fiedorczyk, Białystok: Wydział Prawa Uniwersytetu w Białymstoku 2003, s. 557-559.
} 
zapadł w 1929 r. niekorzystny dla Skarbu Państwa wyrok w pierwszej instancji. Prokuratoria wniosła apelację opartą na art. XIX traktatu ryskiego z $1921 \mathrm{r}^{17}$

Procesy byłych właścicieli kolei o odszkodowanie za przejęcie przez państwo ich linii kolejowych, które jeszcze przez dawne władze okupacyjne zostały przejęte na cele użyteczności publicznej, były polem aktywności Prokuratorii Generalnej przez długie lata. W 1935 r. zawisł przed sądem spór z powództwa Banku Cukrownictwa o zapłatę odszkodowania za eksploatację kolejki wąskotorowej „Wymysłów-Karczmiska-Rybaki-Port Wisła” w okresie od 1918 do 1934 r. Prokuratoria obronę w tym procesie oparła o zarzut niedopuszczalności drogi sądowej. Stanowisko wywiedziono z art. 4 ustawy z 1920 r. o przejęciu kolei. Sąd I instancji uwzględnił stanowisko Prokuratorii ${ }^{18}$. W 1937 r. sprawa trafiła na forum SN, który na podstawie art. $40 \S 1$ ustawy o ustroju sądów powszechnych z 1928 r. przedstawił siedmioosobowemu składowi pytanie prawne o dopuszczalność drogi sądowej w tych sprawach ${ }^{19}$. SN wyrokiem z 1938 r. uznał stanowisko Prokuratorii za niezasadne. Zdaniem SN droga sądowa w sprawach wynikających z ustawy z 1920 r. o przejęciu kolei służyła zainteresowanym stronom. Stanowisko uzasadniono tym, że art. 4 ustawy z 1920 r. o przejęciu kolei przewidywał upoważnienie Ministra Kolei Żelaznych do wydania przepisów o zaspokojeniu osób trzecich, to jednak minister nie wydał odpowiednich przepisów. Dochodzone przez stronę w procesie prawo miało według SN prywatny charakter, a nie publiczny, dlatego też droga sądowa była dopuszczalna. Prokuratoria w sporze broniła tezy, że sam fakt upoważnienia ministra w drodze ustawy do wydania przepisów regulujących zaspokajanie pretensji powstałych na skutek zastosowania przepisów ustawy z 1920 r., przesądzał o niedopuszczalności drogi sądowej dla rozstrzygania tego rodzajów sporów ${ }^{20}$.

\section{Sprawy taryfowe}

W sprawach taryf przewozowych czynności Prokuratorii polegały na interpretacji właściwych regulacji oraz zastępstwie procesowym w sporach o zapłatę, dopłatę lub zwrot należności przewozowych i ubocznych w postaci opłat postojowych, opłat za odprawę celną czy za prace fizyczne wykonywane przez pracowników kolejowych agencji celnych.

\footnotetext{
${ }^{17}$ Traktat pokoju z dnia 18 marca 1921 r. między Polską a Rosją i Ukrainą podpisany w Rydze dnia 18 marca 1921 r. Dz.U. z 1921 r., Nr 49, poz. 300; SPPG-1929, s. 69.

18 SPPG-1935, s. 134.

${ }^{19}$ SPPG-1937, s. 174

${ }^{20}$ SPPG-1938, s. 182.
} 
Prowadzenie spraw taryfowych napotykało poważne utrudnienia. Prokuratoria $\mathrm{w}$ wielu opiniach i sprawozdaniach rocznych wskazywała ułomności systemu prawnego dla tego rodzaju stosunków prawnych. Do poważnych niedociągnięć Prezes Prokuratorii w swoim sprawozdaniu za rok 1926 zaliczył: brak przepisów wydanych w drodze ustawodawczej normujących warunki przewozu i odpowiedzialności kolei, niedokładność i wadliwą redakcję taryf, niestabilność postanowień taryfowych, wydawanie przepisów przewozowych sprzecznych $\mathrm{z}$ postanowieniami ustaw, stosowanie przez władze kolejowe, zwłaszcza w zakresie obrotu międzynarodowego przepisów nienależycie ogłoszonych ${ }^{21}$. Uwagi powyższe szczególnie mocno były aktualne dla taryf eksportowych, zwłaszcza w stosunkach z Wolnym Miastem Gdańsk. Postulaty Prokuratorii dotyczące poprawniejszej redakcji postanowień taryfowych były uwzględniane. Jednak w dalszym ciągu liczba sporów powstałych na tle odmiennej interpretacji taryf była znaczna. Procesy czynne i bierne o zapłatę lub zwrot mylnie obliczonej taryfy przewozowej sięgały swoją wartością kwot wysokich, często przekraczających 100.000 zł i stanowiły większą część procesów agendy kolejowej ${ }^{22}$. Orzecznictwo sądów, w tym także SN, zgodne było z interesem kolei artykułowanym przez Prokuratorię.

Szczególne znaczenie prawne, zwłaszcza dla spraw przewozu międzynarodowego, miała kwestia stosunku konwencji berneńskiej do postanowień taryf kolejowych. W wyłaniających się na tym tle sporach Prokuratoria z powodzeniem broniła zasady, że przepisy krajowe obowiązywały w obrocie międzynarodowym, jeżeli ich regulacje idące nawet dalej niż postanowienia konwencji nie stały z nią w sprzeczności ${ }^{23}$. W 1929 r. w kilku procesach Prokuratoria uzyskała w sądach potwierdzenie zasady, że pobieranie różnych należności ubocznych w obrocie międzynarodowym nie stało w sprzeczności z konwencją berneńską, o ile należności pobrane na rzecz danego państwa były ogłoszone w taryfie państwa, które uczestniczyło w przewozie ${ }^{24}$.

Liczne i skomplikowane były procesy taryfowe prowadzone przed sądami gdańskimi. Zasadniczą wątpliwość prawną stanowiła kwestia, czy eksport do Gdańska był eksportem zagranicznym w rozumieniu polskich taryf wyjątkowych $^{25}$. W 1929 r. orzecznictwo sądów gdańskich ujednoliciło się. Wywóz do Gdańska towarów uznany został za niepodpadający pod prawno-taryfowe

\footnotetext{
${ }^{21}$ SPPG-1926, s. 92; SPPG-1928, s. 100; SPPG-1929, s. 72.

22 SPPG-1928, s. 101; SPPG-1930, s. 84.

${ }^{23}$ SPPG-1928, s. 101.

${ }^{24}$ SPPG-1929, s. 72.

${ }^{25}$ SPPG-1928, s. 100.
} 
określenie eksportu zagranicznego ${ }^{26}$. Poważny wpływ na ukształtowanie się orzecznictwa sądów gdańskich miało wprowadzenie z dniem 1 listopada $1928 \mathrm{r}$. na obszarze Wolnego Miasta Gdańsk polskich przepisów przewozowych i taryfowych ${ }^{27}$.

Do spraw tego typu należy włączyć procesy wyłaniające się z umów przewozu, lecz nie przewozu towarowego a osobowego. Najliczniejszą kategorią procesów tego typu były procesy czynne o zapłatę należności za przejazd bez ważnego biletu lub dopłatę z powodu nadużyć ulg taryfowych. Sprawy tego rodzaju nie nasuwały żadnych poważniejszych problemów prawnych czy faktycznych.

\section{Sprawy odszkodowawcze}

Kolejną grupą spraw kolejowych przysparzających Prokuratorii licznych czynności służbowych były sprawy o zapłatę odszkodowania za szkody powstałe w związku z działalnością przedsiębiorstwa kolejowego. Do tej grupy należały sprawy o naprawienie szkód powstałych z powodu niewykonania lub nienależytego wykonania umów przewozu albo spowodowanych ruchem pociągów, czy wywłaszczeń gruntów na cele kolejowe.

Niewykonanie lub nienależyte wykonanie umowy przewozu spowodowane najczęściej było uszkodzeniem, zniszczeniem lub utratą przez przewoźnika przedmiotu umowy, a także opóźnieniem w jej wykonaniu lub mylnym doręczeniem. Sprawy odszkodowawcze tego typu, nieliczne w początkowych latach działalności Prokuratorii z powodu ograniczenia odpowiedzialności kolei za przesyłki oraz powojennego i walutowego kryzysu, wraz ze wzrostem stabilizacji i uchyleniem w 1923 r. ograniczeń odpowiedzialności, stale rosły ${ }^{28}$. W prowadzonych procesach Prokuratoria broniąc kolei polskich uzyskała w wielu orzeczeniach korzystne rozstrzygnięcia, mające istotny wpływ na ukształtowanie zasad odpowiedzialności i rozmiarów odszkodowania za szkody przewozowe. W 1934 r. SN sformułował pogląd, że przepisy powszechnego prawa cywilnego o obowiązku wynagrodzenia szkody wyrządzonej deliktem nie mogły być w pełni stosowane do PKP. Odpowiedzialność PKP jako przewoźnika określona była specjalnymi przepisami przewozowymi, które nakazywały przyjmować za podstawę wymiaru odszkodowania rzeczywiste obniżenie wartości uszkodzonych przedmiotów, bez względu na dalsze uszczerbki, które mogły powstać w majątku osoby korzystającej z usług kolei z powodu

\footnotetext{
${ }^{26}$ SPPG-1929, s. 73.

27 Tamże.

${ }^{28}$ SPPG-1926, s. 75; SPPG-1928, s. 101.
} 
uszkodzenia rzeczy oddanej do przewozu. Wysokość odszkodowania wynikać miała $z$ różnicy między wartością towaru nieuszkodzonego a wartością towaru po uszkodzeniu ${ }^{29}$. W licznych sprawach związanych $\mathrm{z}$ odpowiedzialnością za skradziony na kolei węgiel i żelazo, Prokuratoria starała się doprowadzić do uznania w orzecznictwie zasady, że sam fakt kradzieży przesyłki w czasie przewozu miał zwalniać kolej z odpowiedzialności w wyniku twierdzenia, że zdarzenie to miało charakter siły wyższej ${ }^{30}$. Praktyka sądowa niezmiennie odmawiała uznania kradzieży za zdarzenie o cechach siły wyższej ${ }^{31}$.

Poważne znaczenie dla ustalenia zasad odpowiedzialności kolei z tytułu odszkodowania za przesyłkę miał wywołany przez Prokuratorię wyrok SN, w którym uznano, że nawet w wypadku niestwierdzenia w liście przewozowym wad opakowania przesyłki, nadawca odpowiadał za tego rodzaju widoczne wady, jeżeli kolej udowodniła, że istniały one w chwili nadania przesyłki do przewozu ${ }^{32}$. W 1935 r. SN rozstrzygnął korzystnie dla Prokuratorii Generalnej sprawy, w których sporny był związek przyczynowy między szkodą a faktem przewożenia towarów wagonami odkrytymi lub specyfiką przewożonych towarów łatwopalnych ewentualnie nadanych do przewozu w nieodpowiednim opakowaniu ${ }^{33}$. Na wzmiankę zasługuje także wyrok SN uzyskany w 1938 r. przez Prokuratorię, w którym uznano, że kolej nie odpowiadała za szkody spowodowane padnięciem przewożonego bydła $\mathrm{z}$ uwagi na uciążliwość transportu, o ile termin dokonania przewozu został zachowany ${ }^{34}$.

Podstawowym źródłem procesów o odszkodowanie za szkody związane $\mathrm{z}$ ruchem przedsiębiorstwa kolejowego były szkody wyrządzone pożarami wywołanymi iskrami parowozów. Sprawy tego typu kończyły się z zasady niepowodzeniem dla Skarbu, a później dla PKP. Aktywność Prokuratorii w tych procesach koncentrowała się na zwalczaniu wysokości żądanego odszkodowania. Podejmowano także próby zmierzające do zmiany orzecznictwa sądów, które według opinii Prokuratorii zbyt rygorystycznie interpretowały dzielnicowe ustawodawstwo w zakresie ruchu kolejowego, w szczególności w ramach obowiązującej zasady odpowiedzialności za skutek ${ }^{35}$. Częstym zjawiskiem było też przypisanie odpowiedzialności kolei pomimo wykazywania przez Prokuratorię prawidłowości funkcjonowania kolejowych urządzeń

\footnotetext{
${ }^{29}$ Wyrok SN z 16 stycznia 1934 r. C.I.564/33 (SPPG-1934, s. 163).

${ }^{30}$ SPPG-1934, s. 164.

${ }^{31}$ SPPG-1935, s. 143.

${ }^{32}$ SPPG-1934, s. 164.

${ }^{33}$ SPPG-1935, s. 143.

${ }^{34}$ Wyrok SN z 8 września 1938 r. L.C.II. 148/38 (SPPG-1938, s. 195).

${ }^{35}$ SPPG-1928, s. 99.
} 
ochronnych (iskrochronów) i braku dowodów bezpośrednich przyczyny pożarów. Sądy najczęściej opierały się jednak na dowodach pośrednich ${ }^{36}$. Do przypisania kolei odpowiedzialności często wystarczał sam fakt przejazdu pociągu w krótkim odstępie czasu od pożaru albo stwierdzenie, że wiatr wiał od strony torowiska $\mathrm{w}$ kierunku pogorzeliska ${ }^{37}$. Z powodu niekorzystnego orzecznictwa $\mathrm{w}$ sprawach o naprawienie szkód powstałych w wyniku pożarów wywoływanych przez parowozy, Prokuratoria nieustannie podnosiła potrzebę ujednolicenia ustawodawstwa dotyczącego odpowiedzialności kolei i uchylenia przestarzałych i nieodpowiadających postępowi cywilizacyjnemu ustaw b. państw zaborczych. Brak działań legislacyjnych spowodował, że władze kolejowe w celu zmniejszenia liczby tych procesów podjęły akcję zmierzającą do uregulowania spraw związanych z tzw. pasem bezpieczeństwa i unowocześnienia technicznych środków uniemożliwiających wylatywanie iskier z komina parowozu. Akcja przyniosła skutek, gdyż liczba spraw o odszkodowanie za szkody pożarowe w 1938 r. znacznie spadła ${ }^{38}$.

Postulaty niezwłocznego wprowadzenia w życie ujednoliconego ustawodawstwa polskiego odnosiły się także do przepisów regulujących odpowiedzialność kolei za skutki wypadków powodujących śmierć lub uszkodzenie ciała $^{39}$. Konstrukcja odpowiedzialności kolei za śmierć i uszczerbki na ciele i zdrowiu zasadzała się na domniemaniu winy kolei. W 1937 r. SN uznał, że niemiecka ustawa z 7 czerwca 1871 r. o odpowiedzialności kolei obejmowała nie tylko wypadki spowodowane przez pociąg będący w ruchu, ale wszystkie wypadki związane ogólnie z ruchem kolejowym, do których zaliczono wypadki przy wsiadaniu i wysiadaniu z pociągu czy wypadki na peronie kolejowym $^{40}$. Prokuratoria podnosiła konieczność rewizji tych zasad z powodu rozpowszechnienia lokomocji mechanicznej i coraz szerszej znajomości niebezpieczeństw związanych z rozwojem komunikacji ${ }^{41}$. Powyższe poglądy Prokuratorii znalazły uznanie w orzeczeniu SN, który w jednej ze spraw oddalił powództwo o odszkodowanie z powodu uszkodzenia ciała, motywując rozstrzygnięcie tym, że ludność miała obowiązek liczenia się z rozwojem środków komunikacji i dokładania przy kontaktach z koleją wyższego stopnia staranności i uwagi ${ }^{42}$.

\footnotetext{
${ }^{36}$ SPPG-1934, s. 160.

${ }^{37}$ SPPG-1938, s. 184.

${ }^{38}$ Tamże.

${ }^{39}$ SPPG-1938, s. 185.

${ }^{40}$ Wyrok SN z 30 września 1937 r. C.III 3494/36 (SPPG-1937, s. 181).

${ }^{41}$ SPPG-1928, s. 100.

${ }^{42}$ Wyrok SN z 15 listopada 1937 r. L.C.II 1070/37 (SPPG-1937, s. 183).
} 
Orzecznictwo sądów w procesach o zasądzenie od kolei odszkodowania czy stałej renty za śmierć lub uszkodzenie ciała spowodowane ruchem kolei było, dzięki staraniom Prokuratorii, znacznie korzystniejsze dla interesu publicznego. Wynikało to $\mathrm{z}$ faktu uwzględniania przy rozstrzyganiu sprawy okoliczności związanych z zawinionym postępowaniem pokrzywdzonego. W 1930 r. SN wydał w sprawie prowadzonej przez Prokuratorię wyrok zawierający tezę, że do wykluczenia odpowiedzialności kolei za wypadek w ruchu wystarczało wykazanie po stronie poszkodowanej winy, choćby w najlżejszym stopniu ${ }^{43}$. Sukcesem Prokuratorii było także ustalenie w orzecznictwie poglądu o konieczności przestrzegania przez podróżnych i inne osoby ostrożności w obrębie urządzeń kolejowych ${ }^{44}$. W coraz częstszych sprawach wynikających ze zderzeń pociągów $\mathrm{z}$ pojazdami samochodowymi, sądy przyjmowały z reguły zasadę winy podzielnej ${ }^{45}$. W $1934 \mathrm{r}$. SN wydał wyrok o doniosłym znaczeniu dla spraw, w których stan faktyczny wynikał ze zderzenia się pojazdu mechanicznego z pociągiem. Prokuratoria doprowadziła do uznania zasady prawnej, że w tego typu sprawach nie miały zastosowania przepisy kolejowe czy automobilowe, lecz przepisy powszechnego prawa cywilnego ${ }^{46}$. Istotnym elementem dla ustalenia odpowiedzialności w sporach wywołanych wypadkami na przejazdach kolejowych było rozstrzygnięcie charakteru prawnego przepisów normujących obowiązek kolei zabezpieczenia przejazdów. Istniał spór co do mocy prawnej przepisów wyznaczających miejsca przejazdowe, które miały być odpowiednio zabezpieczone. Przepisy Ministra Komunikacji ogłaszano w Dzienniku Taryf i Zarządzeń Kolejowych, z tego też powodu nie było pewne, czy należało je traktować jako powszechne normy wyznaczające granice obowiązku kolei strzeżenia przejazdów, czy jedynie jako przepisy wewnętrzne, które nie wykluczały badania przez sąd $\mathrm{w}$ poszczególnych przypadkach istnienia okoliczności mających wpływ na bezpieczeństwo przejazdu i w konsekwencji na odpowiedzialność kolei. Wątpliwości prawne rozstrzygnął w 1936 r. SN. Uznano, że przepisy nakazujące Ministrowi Komunikacji wyznaczanie miejsca przejazdu, które powinno być zabezpieczone, nie ograniczały sądu w badaniu w konkretnym wypadku, czy względy bezpieczeństwa nie wymagały stałego strzeżenia prze$\mathrm{jazdu}^{47}$. Prowadząca przed SN sprawę Prokuratoria uznała to rozstrzygnięcie dla

\footnotetext{
${ }^{43}$ Wyrok SN z 30 listopada 1935 r. C.II. 1864/35 (SPPG-1936, s. 153); SPPG-1930, s. 82.

${ }^{44}$ SPPG-1936, s. 154.

${ }^{45}$ SPPG-1930, s. 82.

${ }^{46}$ Wyrok SN z 7 marca 1934 r. C.II. Rw. 29-22/33 (SPPG-1934, s. 163).

${ }^{47}$ Wyrok SN z 14 czerwca 1936 r. C.II. 2607/35 (SPPG-1936, s. 152).
} 
kolei za niekorzystne ${ }^{48}$. Podobnie miała się rzecz z oceną rozstrzygnięcia SN, który w 1937 r. ${ }^{49}$ uznał, że brak zapory kolejowej w miejscu, gdzie powinna się znajdować, mógł uzasadniać przyjęcie winy mieszanej nawet wtedy, gdy postępowanie wykazało oczywistą lekkomyślność poszkodowanego.

W sprawie nawiązki za ból wywołany zdarzeniami związanymi z ruchem kolei, czy też krzywd z powodu śmierci osoby bliskiej, Prokuratoria wypowiadała się często. W 1928 r. Prokuratoria zgłosiła postulat de lege ferenda, by wzorem niemieckim usunąć nawiązkę z zakresu roszczeń odszkodowawczych do kolei z tytułu uszkodzeń ciała ${ }^{50}$. Kodeks zobowiązań wprowadził jednak ten rodzaj zadośćuczynienia ${ }^{51}$. W 1936 r. SN, rozstrzygając sprawę związaną z katastrofą kolejową pod Krzeszowicami, przyznał powódce zadośćuczynienie za krzywdę moralną i orzekł, wbrew stanowisku Prokuratorii, że przy ocenie wielkości odszkodowania za skutki wypadków kolejowych miały zastosowanie ogólne przepisy Kodeksu zobowiązań ${ }^{52}$.

Wejście w życie polskiego Kodeksu zobowiązań z 1933 r. wywołało kontrowersje związane $\mathrm{z}$ określeniem kręgu osób uprawnionych do żądania naprawienia szkody. Prokuratoria oponowała przeciwko żądaniom podnoszonym przez osoby, które nie były utrzymywane na podstawie ustawowego obowiązku przez osobę zmarłą w wyniku wypadku kolejowego. Prokuratoria przeciwstawiała się również $\mathrm{w}$ tych sprawach przysądzaniu zaliczek na koszty leczenia lub skapitalizowanych rent zarobkowych ${ }^{53}$.

Prokuratoria $\mathrm{w}$ sprawach o odszkodowania za nieszczęśliwe wypadki uzyskała jeszcze w SN uznanie, że przy obliczaniu strat osoby bezpośrednio poszkodowanej należało przyjąć jej cały zarobek, odnośnie zaś do pozostałych członków rodziny osoby poszkodowanej, jedynie sumy potrzebne na ich utrzymanie $^{54}$. Za podstawę do obliczenia wysokości odszkodowania winna służyć ustalona $\mathrm{w}$ orzeczeniu lekarskim procentowa utrata zdolności zarobkowej $\mathrm{w}$ związku z udowodnionymi dochodami powoda uzyskiwanymi z własnej pracy i wobec tego wszystkie inne dochody, których wysokość niezależna była od osobistego udziału poszkodowanego, musiały być pomijane bez

\footnotetext{
48 SPPG-1936, s. 152.

${ }^{49}$ SPPG-1937, s. 181.

${ }^{50}$ SPPG-1928, s. 100; SPPG-1931, s. 105.

${ }^{51}$ Rozporządzenie Prezydenta Rzeczypospolitej z 27 października 1933 r. Kodeks zobowiązań art. $165 \S 1$ i art. 166, Dz.U. z 1933 r., Nr 82, poz. 598.

${ }^{52}$ Wyrok SN z 14 lipca 1936 r. II. C.A. 793/35 (SPPG-1936, s. 153).

${ }^{53}$ SPPG-1935, s. 140.

${ }^{54}$ SPPG-1937, s. 181.
} 
względu na ich źródło przy ustalaniu wysokości odszkodowania ${ }^{55}$. W tego typu sporach Prokuratoria z zasady wychodziła z sądu pokonana, choć uznawano za jej sukces liczne przypadki uzyskania w sądzie obniżenia wymiaru odszkodowania w stosunku do żądań pozwów. Poważną część spraw załatwiano ugodowo ${ }^{56}$. Zdarzały się też ważne zwycięstwa procesowe. Najpoważniejszymi sprawami o odszkodowania od kolei za śmierć lub uszczerbek na zdrowiu, w których Prokuratoria odniosła sukcesy, były spory związane z katastrofami kolejowymi. W 1930 r. SN oddalił powództwo o odszkodowanie związane z katastrofą pod Starogardem. Rozstrzygnięcie miało prejudycjalne znaczenie dla pozostałych 60 sporów. Powództwa w tych sprawach zostały ostatecznie cofnięte ${ }^{57}$. Korzystnie dla kolei zakończyły się także spory związane z katastrofą kolejową spowodowaną zamachem w Rzezawie oraz pod Rogowem ${ }^{58}$. W tej ostatniej sprawie SN w 1934 r. oddalił powództwo uznając, że można było zapobiec katastrofie jedynie przy zastosowaniu środków nadzwyczajnych i w takich rozmiarach, których ze względu na koszty nie można było od kolei wymagać. Z tego też powodu SN uznał, że PKP nie ponosiło odpowiedzialności, gdyż zdarzenie miało charakter siły wyższej ${ }^{59}$.

W sprawach o zapłatę odszkodowania za wypadki komunikacyjne powstałe w ruchu autobusowym zorganizowanym przez PKP obowiązywały identyczne, jak przy ruchu kolejowym zasady dotyczące odpowiedzialności. Przeważnie identyczny był też przebieg i wynik sporu ${ }^{60}$.

Zupełnie odmiennie kształtowała się praktyka w sprawach o odszkodowanie za uszczerbki na zdrowiu, inicjowanych powództwami osób, które nie były pracownikami kolei, lecz w związku z wykonywaniem swojego zawodu dopuszczone zostały do poruszania się po terenie kolejowym. Chodziło tu głównie o bagażowych, sprzedawców gazet, papierosów czy środków spożywczych. Prokuratoria w tego typu sporach zajmowała stanowisko, że osoby te obowiązywał specjalny stopień uwagi i ostrożności, który wykluczał odpowiedzialność kolei opartą na przepisach szczególnych, normujących zasady odpowiedzialności ostrzej, niż wynikały one z ogólnych przepisów cywilnych. Sądy powszechne uznawały w orzecznictwie stanowisko Prokuratorii, choć SN w tego typu sprawie się nie wypowiada ${ }^{61}$.

\footnotetext{
${ }^{55}$ SPPG-1938, s. 186.

${ }^{56}$ SPPG-1937, s. 179

${ }^{57}$ SPPG-1930, s. 82.

${ }^{58}$ Tamże.

${ }^{59}$ Wyrok SN z 9 grudnia 1934 r. (SPPG-1935, s. 138).

${ }^{60}$ SPPG-1936, s. 154.

${ }^{61}$ SPPG-1938, s. 190.
} 
W zakresie roszczeń o odszkodowanie za szkody na zdrowiu i życiu wywołanych działaniami funkcjonariuszy kolejowych powołanych do zapewnienia bezpieczeństwa na kolei, Prokuratoria wykazywała brak odpowiedzialności PKP. Obronę opierano na tezie, że czynności organów bezpieczeństwa kolejowego nie miały na celu wyłącznie ochronę majątku PKP, lecz podejmowane były także $\mathrm{w}$ interesie publicznym, związanym choćby z zapewnieniem porządku ruchu czy ochroną urządzeń kolejowych związanych z bezpieczeństwem. Zdaniem Prokuratorii, na taki zakres działania służby bezpieczeństwa kolejowego wskazywała ustawa z 13 marca 1934 r. o ochronie porządku na kolejach użytku publicznego, na mocy której organy ochrony kolei wykonywały na terenie kolejowym funkcje policji, czyli czynności o charakterze publicznoprawnym $^{62}$.

\section{Sprawy pracownicze}

Sprawy o zapłatę odszkodowania lub ustanowienie renty za nieszczęśliwe wypadki na kolei, którym ulegli pracownicy kolei państwowych, stanowiły część agendy kolejowej związanej ze sprawami osobowymi. Stosunki służbowe, emerytalne i rentowe pracowników kolejowych ze względu na brak jednolitego ustawodawstwa stanowiły zawiły przedmiot czynności Prokuratorii Generalnej ${ }^{63}$.

W sprawach związanych z dochodzeniem należności za skutki wypadków w pracy na kolei istotną kategorią czynności zastępstwa prawnego były interwencje prawne w postępowaniu przed Sądem Rozjemczym dla Zakładu Ubezpieczeń od Wypadków we Lwowie ${ }^{64}$. Przedmiotem postępowania były roszczenia o zaopatrzenie rentowe podnoszone przez pracowników kolei. Prezes Prokuratorii Generalnej w 1928 r. pisał, że „stanowisko, jakie sąd ten orzekający ostatecznie zajmował niemal stale na punkcie należności i wysokości roszczeń powodowych, utrudniało znacznie Prokuratorii obronę Skarbu" ${ }^{" 65}$. Wydanie przez Radę Ministów 4 lipca 1929 r. rozporządzenia o zaopatrzeniu

\footnotetext{
${ }^{62}$ Ustawa z dnia 13 marca 1934 r. o ochronie porządku na kolejach użytku publicznego, Dz.U. z 1934 r., Nr 32, poz. 285; SPPG-1938, s. 191.

${ }^{63}$ Do stosunków osobowych i służbowych pracowników PKP odnosiła się także praktyka Prokuratorii Generalnej prowadzona w agendzie ogólnej: M. TKACZUK, Praktyka prawna Prokuratorii Generalnej w sprawach wynikających ze stosunków slużbowych urzędników państwowych, [w:] Ochrona pracy w okresie międzywojennym w Polsce. Studium historyczno-prawne, red. K. Dąbrowski, S. Kwiecień, Lublin: Wydawnictwo KUL 2015, s. 149-163.

${ }^{64}$ Rozporządzenie Ministra Pracy i Opieki Społecznej z dnia 28 maja 1923 r. dotyczące siedziby i organizacji Sądów Rozjemczych dla Zakładu Ubezpieczenia od wypadków we Lwowie, Dz.U. z 1923 r., Nr 94, poz. 749.

${ }^{65}$ SPPG-1928, s. 97.
} 
emerytalnym pracowników PKP oraz wdów i sierot po nich, a także uregulowanie tym rozporządzeniem odszkodowań za nieszczęśliwe wypadki wygasiło spory zawisłe przed Sądem Rozjemczym ${ }^{66}$.

Inną grupę tego typu spraw, absorbującą przez kilka lat oddziały Prokuratorii Generalnej we Lwowie i Krakowie, stanowiły procesy byłych pracowników kolejowych, członków dawnego Zawodowego Zakładu Ubezpieczenia po wypadkach austriackich kolei państwowych. Przedmiotem tych procesów były roszczenia o wypłatę rent wypadkowych, których wypłata została przez władze kolejowe wstrzymana z dniem 1 października 1921 r. w związku z wejściem w życie ustawy emerytalnej ${ }^{67}$. Kwestia kognicji w tych sprawach była sporna. Prokuratoria na żądanie Ministerstwa Komunikacji wszczęła przed Trybunałem Kompetencyjnym spór o właściwość między ministerstwem a sądami powszechnymi. Wyrokiem z 21 grudnia 1928 r. Trybunał Kompetencyjny potwierdził właściwość sądów powszechnych w tego typu sprawach $^{68}$. Brak ratyfikacji zawartej w 1923 r. konwencji międzynarodowej uniemożliwiał Skarbowi Państwa przejęcie odpowiedniej części aktywów i zobowiązań Zawodowego Zakładu Ubezpieczeń, co miało wpływ na zawiły stan tych spraw ${ }^{69}$.

Wydane w 1934 r. na podstawie rozporządzenia Prezydenta Rzeczypospolitej o utworzeniu PKP rozporządzenie Rady Ministrów ustaliło prawa pracowników kolejowych oraz określiło zasady ich dochodzenia. W tego typu sprawach, dotyczących roszczeń pracowników kolei i ich rodzin podnoszonych na terenie województw środkowych i wschodnich, Prokuratoria podnosiła zarzut niedopuszczalności drogi sądowej. Stanowisko opierano na interpretacji art. II pkt 7 rozporządzenia Prezydenta Rzeczypospolitej z 27 października 1933 r. o przepisach wprowadzających Kodeks zobowiązań ${ }^{70}$. Prokuratoria wywodziła z tego przepisu, że wyłączną podstawę do oceny tego rodzaju odszkodowania stanowiło rozporządzenie Rady Ministrów z 28 stycznia 1934 r. o zaopatrzeniu emerytalnym i odszkodowaniu za nieszczęśliwe wypadki pracowników PKP. Zgodnie zaś z § 4 i 9 tego rozporzą-

\footnotetext{
${ }^{66}$ Rozporządzenie Rady Ministrów z dnia 4 lipca 1929 r. o zaopatrzeniu emerytalnym etatowych pracowników przedsiębiorstwa „Polskie Koleje Państwowe” i zaopatrzeniu pozostałych po nich wdów i sierot oraz o odszkodowaniach za nieszczęśliwe wypadki, Dz.U. z 1929 r., Nr 57, poz. 448.

${ }^{67}$ Ustawa z dnia 28 lipca 1921 r. o emeryturach funkcjonariuszy państwowych, Dz.U. z 1921 r., $\mathrm{Nr} 70$, poz. 466.

${ }^{68}$ SPPG-1928, s. 97.

${ }^{69}$ SPPG-1928, s. 97-98.

${ }^{70}$ Rozporządzenie Prezydenta Rzeczypospolitej z dnia 27 października 1933 r. o przepisach wprowadzających kodeks zobowiązań, Dz.U. z 1933 r., Nr 82, poz. 599.
} 
dzenia właściwą drogą dla dochodzenia praw majątkowych było wyłącznie postępowanie administracyjne ${ }^{71}$.

\section{Sprawy wywlaszczeniowe i dotyczące nieruchomości kolejowych}

Interwencje Prokuratorii Generalnej w sprawach związanych z wywłaszczaniem nieruchomości na cele kolejowe podejmowane były w zakresie postępowania administracyjnego oraz sądowego postępowania spornego i niespornego. Podstawowym zadaniem Prokuratorii w tego typu sprawach była ochrona interesu kolei w zakresie ustalania ceny odszkodowania za wywłaszczanie. Spory odnośnie do wysokości odszkodowania ustalonego przez władze administracyjne dawały powód do licznych procesów prowadzonych przez Prokuratorię. Do poważniejszych spraw tej kategorii należały spory o odszkodowanie za wywłaszczone grunty w związku z budową linii kolejowej „Herby-Gdynia”, „Kraków-Miechów”, „Cieszyn-Zebrzydowice”, „UstrońWisła-Gębce", dworca kolejowego w Cieszynie, czy z rozbudową warszawskiego węzła kolejowego ${ }^{72}$. Prokuratoria Generalna, obok obrony kolei w procesach o zapłatę odpowiedniego odszkodowania za wywłaszczenie, podejmowała także liczne czynności postępowania niespornego. Były to przede wszystkim czynności w zakresie postępowania wieczystoksięgowego, zmierzające do ujawnienia prawa własności kolei państwowych.

Szeregu spraw wywłaszczeniowych, w szczególności w zakresie kompetencyjnym poznańskiego i katowickiego oddziału Prokuratorii Generalnej, dostarczały pretensje byłych właścicieli, którym odebrano przedmiot ich własności na podstawie decyzji b. władz zaborczych ${ }^{73}$. Kluczowym zagadnieniem w tych sprawach była sporna kwestia zakresu mocy art. 33 dekretu Naczelnika Państwa z 7 lutego 1919 r., dotyczącego utrzymania w mocy wywłaszczeń dokonanych przez b. władze zaborcze i okupacyjne ${ }^{74}$. W opinii wydanej w 1931 r. dla Ministerstwa Komunikacji Prokuratoria wyraziła pogląd o przejściu na własność Skarbu Państwa wywłaszczonych przez byłe rządy zaborcze nieruchomości ${ }^{75}$. Drugim, istotnym momentem tych spraw

\footnotetext{
${ }^{71}$ Rozporządzenie Rady Ministrów z dnia 28 stycznia 1934 r. o zaopatrzeniu emerytalnym i odszkodowaniach za nieszczęśliwe wypadki pracowników przedsiębiorstwa „Polskie Koleje Państwowe", Dz.U. z 1936 r., Nr 20, poz. 169.

${ }^{72}$ SPPG-1936, s. 148; SPPG-1935, s. 135.

${ }^{73}$ SPPG-1938, s. 183.

${ }^{74}$ Dekret Naczelnika Państwa z dnia 7 lutego 1919 r. przepisy tymczasowe o wywłaszczeniu przymusowym na użytek dróg żelaznych i innych dróg komunikacyjnych lądowych i wodnych oraz wszelkich urządzeń użyteczności publicznej, Dz.U. z 1919 r., Nr 14, poz. 162.

${ }^{75}$ SPPG-1931, s. 102.
} 
było ustalenie, w jakich wypadkach należało uznawać Skarb Rzeczypospolitej obowiązanym do wypłaty odszkodowania za wywłaszczenia dokonane przed odzyskaniem niepodległości. Sądy zasądzały odszkodowanie często także z odsetkami za czas od chwili odrodzenia się państwa polskiego. Prokuratoria stanowczo podnosiła, że o ile samo zasądzenie odszkodowania mogło być zasadne, to przyznanie tego typu odsetek nie znajdowało poparcia $\mathrm{w}$ przepisach prawa o postępowaniu wywłaszczeniowym ${ }^{76}$.

Kolejną kategorią spraw agendy kolejowej były stosunki rzeczowe i obligacyjne, których przedmiot stanowiły nieruchomości. Do najliczniejszych należały tu czynności zastępstwa sądowego podejmowane w procesach windykacyjnych. Prokuratoria Generalna imieniem Skarbu Państwa, później zaś PKP, żądała wydania bezprawnie zajętych nieruchomości gruntowych, opuszczenia lokali i budynków kolejowych, w tym bufetów stacyjnych, oddania wydzierżawianych gruntów (np. składowisk). Procesowano się także o zapłatę umówionego czynszu. Liczne były też, szczególnie na obszarze właściwości miejscowej Sądu Apelacyjnego w Wilnie, czynności postępowania niespornego związane $\mathrm{z}$ pierwiastkowymi wpisami własności w księgach wieczystych.

Procesy o wydanie bezprawnie zajętych nieruchomości kolejowych liczne były w jednostkach Prokuratorii Generalnej, których kompetencja miejscowa obejmowała obszar b. zaboru rosyjskiego ${ }^{77}$. Wojenna zawierucha, brak akt b. rosyjskiego zarządu kolejowego oraz niedostatek urządzeń wieczystoksięgowych powodował ogromne trudności w prowadzeniu przez Prokuratorię tych sporów ${ }^{78}$.

W sprawach dotyczących warunków i trybu rozwiązywania umów o prowadzenie restauracji i bufetów kolejowych w budynkach dworcowych oraz eksmisji z lokalu czy zapłaty umówionego czynszu, zasadniczym problemem było ustalenie kwalifikacji prawnej umowy. Prokuratoria stale stała na stanowisku, że umowy te były umowami najmu. Orzecznictwo SN przyjmowało ten pogląd. Jednak sądy w orzecznictwie z początku lat trzydziestych zaczęły traktować te umowy jako dzierżawę prawa. Prokuratoria uznała zmianę orzecznictwa za niekorzystną dla kolei. Winą za zmianę orzecznictwa sądów niższej instancji Prokuratoria obarczyła także zarząd kolejowy, który we wzorach umów tego typu określał je terminem „dzierżawa”. Sprawa miała istotne znaczenie proceduralne, gdyż sprawami najmu bez względu na wartość sporu zajmowały się wyłącznie sądy grodzkie, natomiast kontrowersje

\footnotetext{
${ }^{76}$ SPPG-1938, s. 183

${ }^{77}$ SPPG-1931, s. 102.

78 Tamże; SPPG-1933, s. 114.
} 
były wykorzystywane przez pozwanych do przewlekania postępowania ${ }^{79}$. Ostatecznie orzecznictwo sądów zaakceptowało stanowisko Prokuratorii, choć zdarzały się przypadki, że sądy niższych instancji dopatrywały się w dalszym ciągu w tego typu umowach elementów dzierżawy. Prokuratoria zwalczała takie orzecznictwo w drodze środków odwoławczych ${ }^{80}$.

Prowadzenie przez Prokuratorię spraw najmu budynków i lokali kolejowych przez osoby prywatne na cele działalności gospodarczej czy na cele mieszkaniowe doznało w 1933 r. poważnego ułatwienia. Na mocy rozporządzenia Prezydenta Rzeczypospolitej z 27 października 1933 r. sprawy związane z najmem budynków kolejowych zostały wyłączone spod obowiązywania ustawy o ochronie lokatorów ${ }^{81}$. Dochodzenie praw z umowy najmu Prokuratoria ułatwiała także w ten sposób, że doradzała dyrekcjom kolei zawieranie umów najmu $\mathrm{w}$ formie aktu notarialnego ${ }^{82}$. Zgodnie $\mathrm{z}$ przepisami Kodeksu Postępowania Cywilnego akt notarialny stanowił tytuł egzekucyjny ${ }^{83}$. W sprawach dotyczących najmu placów i składowisk Prokuratoria uzyskała w SN ważny wyrok orzekający, że najem placów i składowisk nie podlegał ochronie przewidywanej przez ustawę o ochronie lokatorów ${ }^{84}$.

\section{WNIOSKI}

W 1919 r. wprowadzono w Polsce model scentralizowanej ochrony interesów prawnych państwa oraz innych podmiotów traktowanych na równi ze Skarbem Państwa. Organem stojącym na straży interesów prawnych o charakterze publicznym oraz majątkowym tych podmiotów była Prokuratoria Generalna Rzeczypospolitej Polskiej. Na mocy ustawy Sejmu Ustawodawczego o utworzeniu Prokuratorii ochronie prawnej urzędu poddano kolej państwową, która do 1926 r. miała charakter jednostki organizacyjnej Skarbu Państwa. Na mocy rozporządzenia Prezydenta Rzeczypospolitej z 24 września 1926 r. państwowy majątek kolejowy skomercjalizowano i utworzono osobę prawną o nazwie Polskie Koleje Państwowe. Kolej w Polsce była podmiotem licznych praw majątkowych i stosunków prawnych. Z tego też powodu prak-

\footnotetext{
${ }^{79}$ SPPG-1935, s. 136.

${ }^{80}$ SPPG-1934, s. 157.

${ }^{81}$ Rozporządzenie Prezydenta Rzeczypospolitej z dnia 27 października 1933 r. o zmianie ustawy o ochronie lokatorów, Dz.U. z 1933 r., Nr 84, poz. 625.

${ }^{82}$ SPPG-1938, s. 182.

${ }^{83}$ Kodeks postępowania cywilnego - tekst jednolity ogłoszony na podstawie obwieszczenia ministra sprawiedliwości z 1 grudnia 1932 r., Dz.U. z 1932 r., Nr 112, poz. 934 - art. 527 ust. 5.

${ }^{84}$ Wyrok SN z 22 stycznia 1935 r. C.IV. 2298/34 (SPPG-1935, s. 136).
} 
tyka prawna Prokuratorii Generalnej w ramach agendy kolejowej była rozległa. Doniosłe znaczenie miały czynności opiniodawcze oraz zastępstwa prawnego podejmowane przez Prokuratorię, których skutkiem było wykształcenie właściwego wyobrażenia o istocie odrębnej od Skarbu Państwa zdolności prawnej przedsiębiorstwa kolejowego. Sprawy taryfowe, odszkodowawcze czy dotyczące majątku kolejowego były równie istotne, w szczególności w zakresie ochrony interesów majątkowych podmiotu wyposażonego we własność publiczną. Liczba spraw prowadzonych w ramach agendy kolejowej jest trudna do ustalenia, gdyż sprawozdania Prezesa Prokuratorii podawały liczby poszczególnych typów czynności, bez podziału na agendy. Prowadzenie spraw kolejowych wymagało od referendarzy i radców Prokuratorii wykonujących czynności służbowe gruntownej wiedzy prawniczej. Prokuratoria Generalna w sposób należyty chroniła interes majątkowy i publicznoprawny kolei państwowych. Jej działania w tej sferze pozwoliły porządkować prawo ustroju kolejowego oraz znacząco przyczyniły się do właściwej interpretacji prawa regulującego stosunki prawne o charakterze majątkowym, których podmiotem były PKP.

\section{BIBLIOGRAFIA}

ŹRÓDŁA

Sprawozdanie stenograficzne z posiedzenia Sejmu Ustawodawczego z dnia 31 lipca $1919 \mathrm{r}$.

Druk sejmowy Sejmu Ustawodawczego nr 861.

Sprawozdania Prezesa Prokuratorii Generalnej Rzeczypospolitej Polskiej z okresu międzywojennego.

\section{ŹRÓDEA PRAWA}

Dekret Naczelnika Państwa z dnia 7 lutego 1919 r. przepisy tymczasowe o wywłaszczeniu przymusowym na użytek dróg żelaznych i innych dróg komunikacyjnych lądowych i wodnych oraz wszelkich urządzeń użyteczności publicznej, Dz.U. z 1919 r., Nr 14, poz. 162.

Dekret z dnia 7 lutego 1919 r. w przedmiocie utworzenia Prokuratorii Generalnej Rzeczypospolitej Polskiej, Dz. Pr. z 1919 r., Nr 14, poz. 181.

Ustawa z dnia 31 lipca 1919 r. w przedmiocie utworzenia Prokuratorii Generalnej Rzeczypospolitej Polskiej, Dz.U. z 1919 r., Nr 75, poz. 390.

Ustawa z dnia 14 grudnia 1920 r. o przejęciu kolei zbudowanych przez b. władze okupacyjne, pod zarząd Ministerstwa Kolei Żelaznych, Dz.U. z 1921 r., Nr 3, poz. 5.

Traktat pokoju z dnia 18 marca 1921 r. między Polską a Rosją i Ukrainą podpisany w Rydze dnia 18 marca 1921 r., Dz.U. z 1921 r., Nr 49, poz. 300.

Ustawa z dnia 28 lipca 1921 r. o emeryturach funkcjonariuszy państwowych, Dz.U. z 1921 r., Nr 70, poz. 466. 
Rozporządzenie Ministra Pracy i Opieki Społecznej z dnia 28 maja 1923 r. dotyczące siedziby i organizacji Sądów Rozjemczych dla Zakładu Ubezpieczenia od wypadków we Lwowie, Dz.U. z 1923 r., Nr 94, poz. 749.

Rozporządzenie Prezydenta Rzeczypospolitej z dnia 9 grudnia 1924 r. o zmianie ustroju Prokuratorii Generalnej Rzeczypospolitej Polskiej, Dz.U. z 1924 r., Nr 107, poz. 967.

Rozporządzenie Prezydenta Rzeczypospolitej z dnia 24 września 1926 r. o utworzeniu przedsiębiorstwa „Polskie Koleje Państwowe”, Dz.U. z 1926 r., Nr 97, poz. 568.

Rozporządzenie Prezydenta Rzeczypospolitej z dnia 6 lutego 1928 r. - Prawo o ustroju sądów powszechnych, Dz.U. z 1928 r., Nr 12, poz. 93.

Rozporządzenie Rady Ministrów z dnia 4 lipca 1929 r. o zaopatrzeniu emerytalnym etatowych pracowników przedsiębiorstwa „Polskie Koleje Państwowe” i zaopatrzeniu pozostałych po nich wdów i sierot oraz o odszkodowaniach za nieszczęśliwe wypadki, Dz.U. z 1929 r., Nr 57, poz. 448.

Kodeks postępowania cywilnego - tekst jednolity ogłoszony na podstawie obwieszczenia ministra sprawiedliwości z 1 grudnia 1932 r., Dz.U. z 1932 r., Nr 112, poz. 934.

Rozporządzenie Prezydenta Rzeczypospolitej z 27 października 1933 r. - Kodeks zobowiązań, Dz.U. z 1933 r., Nr 82, poz. 598.

Rozporządzenie Prezydenta Rzeczypospolitej z dnia 27 października 1933 r. o przepisach wprowadzających kodeks zobowiązań, Dz.U. z 1933 r., Nr 82, poz. 599.

Rozporządzenie Prezydenta Rzeczypospolitej z dnia 27 października 1933 r. o zmianie ustawy o ochronie lokatorów, Dz.U. z 1933 r., Nr 84, poz. 625.

Rozporządzenie Rady Ministrów z dnia 28 stycznia 1934 r. o zaopatrzeniu emerytalnym i odszkodowaniach za nieszczęśliwe wypadki pracowników przedsiębiorstwa „Polskie Koleje Państwowe", Dz.U. z 1936 r., Nr 20, poz. 169.

Ustawa z dnia 13 marca 1934 r. o ochronie porządku na kolejach użytku publicznego, Dz.U. z 1934 r., Nr 32, poz. 285.

\section{ORZECZNICTWO}

Orzeczenie połączonych Izb SN z 8 czerwca 1929 r. Nr I. N 78/29 (SPPG-1929, s. 68).

Wyrok SN z 16 stycznia 1934 r. C.I.564/33 (SPPG-1934, s. 163).

Wyrok SN z 7 marca 1934 r. C.II. Rw. 29-22/33 (SPPG-1934, s. 163).

Wyrok SN z 9 grudnia 1934 r. (SPPG-1935, s. 138).

Wyrok SN z 22 stycznia 1935 r. C.IV. 2298/34 (SPPG-1935, s. 136).

Wyrok SN z 6 czerwca 1935 r. (SPPG-1935, s. 134).

Wyrok SN z 30 listopada 1935 r. C.II. 1864/35 (SPPG-1936, s. 153).

Wyrok SN z 14 czerwca 1936 r. C.II. 2607/35 (SPPG-1936, s. 152).

Wyrok SN z 14 lipca 1936 r. II. C.A. 793/35 (SPPG-1936, s. 153).

Wyrok SN z 30 września 1937 r. C.III 3494/36 (SPPG-1937, s. 181).

Wyrok SN z 15 listopada 1937 r. L.C.II 1070/37 (SPPG-1937, s. 183).

Wyrok SN z 8 września 1938 r. L.C.II. 148/38 (SPPG-1938, s. 195). 


\section{LITERATURA}

SiteK Bronisław Włodzimierz: Wybrane systemy prawnej i instytucjonalnej ochrony praw i interesów państwa, Warszawa: Difin 2020.

TKACZUK Marek: Sprawy międzynarodowe w praktyce prawnej Prokuratorii Generalnej RP w dwudziestoleciu międzywojennym, [w:] Wielokulturowość polskiego pogranicza. Ludzie idee - prawo, red. Adam Lityński, Piotr Fiedorczyk, Białystok: Wydział Prawa Uniwersytetu w Białymstoku 2003, s. 557-559.

TKACZUK Marek: Praktyka prawna Prokuratorii Generalnej w sprawach wynikających ze stosunków służbowych urzędników państwowych, [w:] Ochrona pracy w okresie międzywojennym w Polsce. Studium historyczno-prawne, red. Karol Dąbrowski, Sebastian Kwiecień, Lublin: Wydawnictwo KUL 2015, s. 149-163.

\section{SPRAWY DOTYCZACEE KOLEI PAŃSTWOWYCH W PRAKTYCE PRAWNEJ PROKURATORII GENERALNEJ RZECZYPOSPOLITEJ POLSKIEJ \\ W LATACH 1919-1939}

Streszczenie

W 1919 r. na mocy dekretu Tymczasowego Naczelnika Państwa ustanowiono w ustroju państwa polskiego Prokuratorię Generalną Rzeczypospolitej Polskiej. Sejm Ustawodawczy uchylił dekret i zastąpił go ustawą. Nowy porządek prawny pozwolił objąć ochroną prawną udzielaną przez Prokuratorię Generalną, obok majątku Skarbu Państwa, także majątek kolei państwowej. Aktywność Prokuratorii w ramach czynności służbowych obejmowała zastępstwo prawne oraz konsultacje prawne. W ramach agendy kolejowej zajmowano się interpretacją prawa regulującego ustrój kolejowy państwa, a także własnością i zobowiązaniami kolei oraz ochroną interesu publicznego związanego z działaniem kolei państwowych.

Slowa kluczowe: Skarb Państwa; zastępstwo prawne; prawna ochrona interesów majątkowych i publicznych państwa

\section{MATTERS OF THE STATE RAILWAYS IN THE LEGAL PRACTICE OF THE GENERAL COUNSEL'S OFFICE OF THE REPUBLIC OF POLAND} IN THE YEARS 1919-1939

\section{S u m m a r y}

The General Counsel's Office of the Republic of Poland came into existence by a decree of the Chief of State on 7th February, 1919. On July 31, 1919, the Parliament revoked the decree of the Chief of State and passed the appropriate bill. The General Counsel's Office of the Republic of Poland protected the public and property interests of the Treasury and the Polish State Railways. The judicial replacement and legal opinion were provided in such matters as the interpretation of the law, the property, obligations and the protection of the public and property interests of Polish railways.

Keywords: The State Treasury; legal representation; legal protection of state property and public interests 